\title{
Asiantuntijuus arvioinnissa
}

\author{
Vesa Huotari
}

1990-luvun alussa Rossi $(1990,7)$ uskoi arvioinnin

tarjoavan jännittävimmän ajateltavissa olevan uran

nuorelle sosiaalitieteilijälle. Vajaat kymmenen vuotta

myöhemmin olikin arvioinnin osaajia ilmestynyt siinä

määrin, että tilanne toi Ahosen (1998) mieleen

etiopialaisen kaupungin markkinat ja sen hunaja-

osastolla pörräävät kärpäset. Hän puhuukin arviointi-

hurmiosta. Sen yhtenä seurauksena on ollut arvioinnin

käsitteen hämärtyminen. (Ahonen 1998, 257-259)

Käsitteen selventäminen ei luonnollisestikaan riitä kaikkien arviointiin sosiaalisena käytäntönä liittyvien ongelmien ratkaisemiseen, mutta asiaa ei myöskään edesauta käsitteen hämäryys. Artikkelissani pohdinkin arvioinnin käsitettä ja sen kautta avautuvaa käsitystä asiantuntijuudesta arvioinnissa. Oletan, että arvioinnilla on oma ominaisluonteensa ja että arvioinnin käsitteen on tarkoitus luonnehtia sitä. Nähdäkseni kaikki tällaiset luonnekuvaukset ovat historiallisia. Niissä heijastuvat täten ne moninaiset yhteydet, joissa parempia kuvauksia ja osuvampia käsitteitä tavoitellaan. Arvioinnin luonne ei siis ole absoluuttisesti paljastettavissa, mutta arviointia ei myöskään ole mahdollista reflektoida sitä määrittelemättä. Käsiteanalyysi luokin osaltaan edellytyksiä itsereflektiolle, jonka on katsottu liittyvän läheisesti arviointiin (esim. Raivola 1995, 57; Virtanen 1998).

Vuorensyrjä (1998) katsoo arvioinnin logiikan rakentuvan arvokkaan ja kuvaavan keskinäissuhteelle (vrt. Varto 1995, 340-341). Arvioinnin käsitteellistä ydintä luonnehtii täten sen kohdetta määrittävien käsitteiden eli kohdekuvauksen ja täten määrittyvään kohteeseen yhdistettyjen, sen laatua ilmentävien arvoarvostelmien yhdistelmä.

Kriittinen keskustelu moninaisten kohdekuvausten pätevyydestä on tiedettä rakentava piirre. Kädenvääntö erilaisten arvoarvostelmien perusteltavuudesta luonnehtii puolestaan filosofiaa omana, tieteestä erillisenä toiminnan alueenaan.

Tieteellinen kohdekuvaus ei sellaisenaan täytä arvioinnin tarkoitusta. Perusedellytyksenä jälkimmäiselle on se, että kyseinen kohde saa osakseen jonkin arvoarvostelman (sopiva, paras, tarkoituksenmukainen jne.). Arvioinnin ja tieteen keskinäisyhteys perustuukin näin ollen siihen, että arviointi väistämättä rakentuu jollekin kohdekuvaukselle. Arvioinnin yhteys filosofiaan nojaa puolestaan arvoarvostelman välttämättömyyteen. Arviointi ei täten ole tiedettä, mutta se ei myöskään ole jotakin täysin tieteestä erillistä (filoso- 
fiaa, politiikka, etiikkaa tms.). Voimme hyvinkin ajatella, että olisi olemassa maailma, jossa asioita ei arvotettaisi sellaisiksi tai tällaisiksi, mutta ajatus maailmasta, jossa olisi vain arvoarvostelmia, mutta ei mitään siten tai täten arvotettavaa, vaikuttaa absurdilta.

Kun tarkastelemme kohdekuvausta tai -konseptiota arvioinnin käsitteen aspektina, pohdimme sitä, miten oleva meille ilmenee ja missä määrin tätä ilmenemisen tapaa ja muotoa luonnehtii asianmukaisuus, adekvaattisuus tai osuvuus. Mitä osuvampaan kohdekuvaukseen arviointi perustuu, sitä paremmin arviointi voi palvella halutun tarkoituksen tavoittelua - palvella päätöksentekoa, suunnata toimintaa jne.

Kohdekuvausten - kohdekäsitteiden - pätevyyden kyseenalaistaminen on kaikkea muuta kuin itsestään selvää tai helppoa. ${ }^{1}$ Arvioinnin kohteet ovat yleensä kulttuurisesti ja/tai hallinnollis-poliittisesti annettuja tai osoittamalla määriteltyjä ("tämä ohjelma tässä", "tuo toiminta tuolla”). Ne näyttäytyvät ikään kuin kaikille yhtäläisinä ulkoisina 'maamerkkeinä', joista arjen kuten myös arvioinnin 'kartta' muodostuu ja joiden kautta henkilöt ja heidän pyrkimyksensä paikantuvat ja tulevat sosiaalisesti merkityksellisiksi. Arvioitsijat sijoittuvat osaksi ikään kuin yhteistä ja ainoastaan yhdellä mahdollisella tavalla - usein huomaamatta samalla myös ylhäältä käsin - järjestyvää tapahtumahorisonttia. Arvioinnin kohteista tulee luonteeltaan ja olemukseltaan annettuja. Samalla häipyy näkyvistä se tosiasia, että tapahtumahorisontin täyttäminen kohteilla, konteksteilla ja tuloksilla, on vaatinut sekä käsitteitä että niiden käyttöä. Kun valtaosa arvioijista vielä kokee roolikseen päätöksenteon

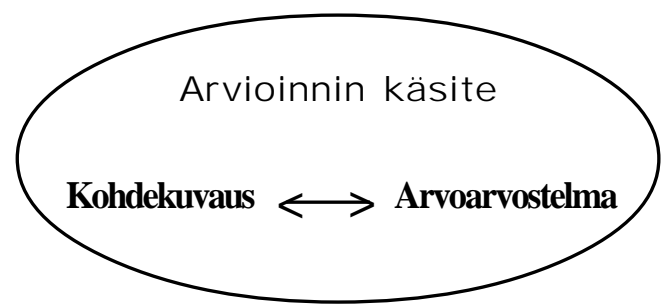

Kuvio 1: Arvioinnin käsite teknisen avustamisen (Raivola 1995, 26) ja lähtee päätöksentekijöiden antamista kohderajauksista, arviointi osaltaan vahvistaa käsitystä kyseisen jäsentämisen ja näkemisen tavan ensisijaisuudesta ja luonnollisuudesta. Tätä lisäksi edesauttaa sellainen naiivi realismi, jonka mukaan paremmat arviointikäytännöt ovat yhtä kuin yhä moninaisempi joukko arvioinnin kohteita (syötteet, prosessi, konteksti, tulokset eri aikaväleillä jne.) ja jossa maailman ajatellaan koostuvan välittömästi annetuista, erillisistä ja toisensa poissulkeville paikoille sijoittuvista tekijöistä ja tapahtumista. Arviointihurmiossa jää helposti huomiotta arviointiin uhrattujen resurssien suhde siitä mahdollisesti seuraaviin tuottoihin. Se, että arvioinnista on korkeintaan kertomaan, mikä on pielessä, mutta ei sitä, mitä asialle olisi järkevää tehdä, usein paljastuu vasta arvioinnin jälkeen. Tämä onkin keskeinen asiantuntijavallalle altistava arvioinnin osatekijä.

Arvioinnin asiantuntijavaltaistuminen on toinen tekijä, joka arvioinnin kohteiden valtapoliittisen antamisen rinnalla sekä sen sisällä kaventaa mahdollisuuksia kyseenalaistaa kohdekuvausten pätevyyttä. Väite asiantuntijoiden kohdekonseptioiden vahvemmasta "asianmukaisuudesta" erottaa heidät maallikoista. Kun maallikon puhe ei ole tulkittavissa asiantuntijadiskurssin tarjoamien välineiden - käsitteet ja niiden yhteydet avulla, puutteellisuutta haetaan maallikon ymmärryksestä, ei tuosta diskurssista. Maallikon tulisikin rationaalisuuden ja edistyksen nimissä luopua omasta maallikkoudestaan ja hankkia asianmukainen tutkinto, jolloin hänkin näkisi oikeat asiat ja jopa vielä oikein (eikä keskustelua 
itse "asiasta" enää tarvittaisi) (ks. Williamson 1998, 36-49). Kun valta ja tällainen "asiantuntijuus" löytävät toinen toisensa arvioinnin alueella, muille asianosaisille ei juurikaan jää todellista sanansijaa ja kohdekuvaukset sementoituvat ulkoisesti koskemattomaksi osaksi eksperttiyhteiskuntaa. $^{2}$

Jos asiantuntijavaltaistumista voikin pitää keskeisenä keskustelua kohdekuvausten osuvuudesta rajoittavana tekijänä, niin arvoarvostelmien perusteltavuutta arvioinnin osatekijänä rajoittaa romantisoitu, ultrasubjektivistinen näkemys arvottamisesta. Mistä tahansa on yksilöllisten arvoarvostelmien kohteeksi, mutta arviointi edellyttää yhteistä ja tässä mielessä objektivoitavissa olevaa kohdetta. Ajatus arvoarvostelmien yhtenevyydestä tai eriävyydestä - ylipäätään eri arvoarvostelmista - on mielekäs vasta, kun arvoarvostelmilla on yhteinen kohde eli kun ne ovat arvoarvostelmia jostakin, joka on kiinnitetty.

Romantisoituminen tarkoittaa tässä käsitystä, jonka mukaan jokainen arvottaa omalla tavallaan itse omintakeisesti konstruoimiaan kohteita. Tällöin ilmaistut arvoarvostelmat ovat arvoarvostelmia jostakin, joka on tuomittu jäämään hämäräksi. Arvioinnilta yksinkertaisesti puuttuu sen vaatima kiinnekohta, kun ajatellaan, että arvioinnin kohteena on teko, toiminta tai sen tulos juuri sellaisena, kuin se arvoarvostelman tekijälle ilmenee. Haaviin jää tässä runsaasti arvoarvostelmia, mutta ei hitustakaan arviointia.

Kun kohderajaus oletetaan ratkaistuksi ja arvioinnin kohde täten kiinnitetyksi, ko. kohteesta on yksilöllisten arvoarvostelmien viitekohdaksi arvioinnin vaatimassa merkityksessä. Arvioinnin politiikka kiertyy kysymykseen siitä, kuinka edetä yksilöllisistä arvoarvostelmista yhteiseen arvopäätelmään. House $(1995,29)$ näkeekin arvoarvostelmalogiikan laajentamisen yhdeksi arviointiteorian haasteista. Ideaalitilanteessa arviointitutkijoille olisi käytettävissään logiikka, joka osoittaisi tien arvopäätelmiin. Hän uskoo, että kattava sosiaalisen oikeudenmukaisuuden kehys syntyy, kunhan asiasta on aluksi riittävästi keskusteltu ja väitelty (emt., 31). Ajatus oikeudenmukaisuuden yhtälöstä, jossa eriytyvät yksilölliset arvoarvostelmat kääntyisivät päteviksi ja pätevyydeltään kaikille ilmeisiksi arvopäätelmiksi, vaikuttaa utopistiselta.

Arvoarvostelmien yksilöperustaisuudella on olennainen merkitys. Yksilö on ainoa suvereeni arvoarvostelmien esittäjä ja arvovalintojen tekijä. Myyjä voi olla ja usein vielä perustellusti jotakin mieltä ko. kaupankohteen ominaispiirteistä: saapas pitää tutkitusti vettä, auto on todettu huoltovapaaksi, huoneisto on läpitalon huoneisto. Kohdetta koskevan arvoarvostelman osalta - saappaan väri ei miellytä, auto vaikuttaa vanhahtavalta, huoneisto tuntuu tunkkaiselta - hän voi vain ilmaista oman kantansa tai, kuten myyjillä on yleensä tapana, kertoa millaisia arvoarvostelmia "toiset" ovat siitä esittäneet. ${ }^{3}$ Arvoarvostelmien perusta on yksilöllisessä tavassa kokea kyseinen kohde ja vain siinä. Vaikka arvoarvostelmilla ei ole muuta kiinnekohtaa kuin yksilöllinen kokemus, arviointi ei palaudu yksilöllisiksi kokemuksiksi. Arviointi ei ole yhtä kuin henkilökohtainen arvoarvostelma tai joukko näitä. ${ }^{4}$

Romantisoitumista vahvistaa edelleen se, että ajatus jokaisen suvereenista subjektiudesta arvoarvostelmien tekijänä sotketaan ajatukseen jokaisesta suvereenina oman itsensä ja omien intressiensä tuntijana (kun 'tunteminen' sekoitetaan näin 'tietämiseen'). Rajojensa ylitse venytetty ajatus suvereeniudesta johtaa näin helposti näkemykseen, että jokainen on yhtä kykenevä arvioimaan, mikä hänelle itselleen on parasta eli tosiasiallisesti hänen intressiään palvelevaa. Suvereeniudesta arvoarvostelmien tekijänä ei kuitenkaan automaattisesti seuraa suvereenius arvioinnissa. Kysymys on yksinkertaisesti eri asioista. Evaluaatio käsittää aina arvoista juontuvan puolen ohella kohdekonseptiosta juontuvan puolen. Voimme ajatella, että kaikki arvot ovat yhtä lähellä absoluuttisia arvoja. Kaikki kohdekuvaukset eivät kuitenkaan sijoitu samalle viivalle. Jos romantisoitu käsitys etuoikeuttaakin yksilön oman tiedon ja kohottaa sen yli toisten tietämyksen, niin vastakkaisessa ääripäässä jonkun toisen katsotaan aina olevan henkilöä itseään paremmin informoitu jälkimmäisen todellisesta intressistä, objektiivisesta tilanteesta tai varsinaisesta tarpeesta. $^{5}$ 


\section{Arvopäätelmän oikeuttavuus}

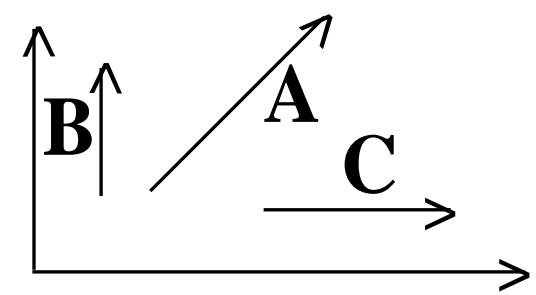

Kohdekuvauksen osuvuus

KUVIO 2. Arvioinnin käsite ja arvioinnin asiantuntijuuden kehittymisen perussuunnat

Realistinen ratkaisu nousee vuoropuhelusta pessimistisen ja ultrasubjektivistisen ääripään välillä (valta asiantuntijoille/asianosaisille). Kun asiantuntijuuden ymmärretään rakentuvan yhä paremmille kohdekuvauksille (totuudellisempia, situationaalisesti relevantimpia, deskriptiivisesti osuvampia ja toiminnallisesti resurssoivampia), sen sisältönä voi olla niin tuntemus omasta itsestä kuin myös tietämys maailmasta. Näille molemmille asaintuntijuuden alueille, joista toisen oikeutus näyttää tietoyhteiskuntakehityksen myötä yhä uhatummalta, on yhteistä muuntuvuus, uudelleen tulkinnallisuus ja epävarmuus. Tietämys itsestä pyrkii pukemaan merkitykseltään yleisiksi sanoiksi jotakin ainutlaatuista ja tietämys maailmasta tulkitsemaan ainutlaatuista jo tunnettujen tapausten jatkeena. Asianosaisten tietämys on usein liian puutteellista, jotta he täysin tuntisivat todellisen tilanteensa, mutta he myös tietävät siitä jotakin sellaista, johon muilla ei ole pääsyä. Kun toinen on ehkä kykenevämpi ennakoimaan, mitä jostakin voi seurata, toinen on parempi kertomaan, mihin hän pyrkii. Eroista arvoarvostelmissaan he voivat vain keskustella.

Jos yhteisymmärrys vallitsee kohdekuvauksesta eli kaikki ovat yhtä mieltä siitä, mikä kuuluu arvioinnin kohteeseen ja mikä taas sen ympäristöön, ratkaistavaksi jää se, miten oikeuttaa ko. kohdetta koskeva arvopäätelmä. Jos oikeuttamisen universaali logiikka oletetaan löydetyksi, ratkaistavaksi jää se, miten valita kilpailevien kohdekonseptioiden väliltä. Heikoimmillaan arviointi rakentuu käsitteelliselle rajaukselle, jossa kohdekuvauksella ei ole mitään yhteyttä todellisuuteen (esim. noitavainot), ja sitä arvotetaan tavalla, jolla ei ole minkäänlaista yhteyttä ko. kohdetta koskeviin yksilöllisiin arvoarvostelmiin. ${ }^{6}$
Erhe arvoarvostelman oikeuttamisessa johtaa asianosaisia harhaan sen suhteen, millä mallilla asiat todellisuudessa ovat.

Arvioinnin arvioinnilla näyttäisi näin olevan kaksi kohdetta. Toisaalta on arvioitava kohdekuvauksen adekvaattisuutta, toisaalta taas tapaa, jolla sitä koskevaan arvopäätelmään päädytään. Arvioinnin käsite itsessään osoittaa täten seuraavat suunnat paremmalle arvioinnille (kuvio 2).

Keskeinen ongelma kohdekuvausten osuvuuden osalta on se, ettei moniksi tieteenaloiksi fragmentoitunut tiede itseasiassa kykene tarjoamaan "todellisuudenmittaisia" luonnehdintoja. Käsitteellisesti hyvinkin perustellut ja syvät kuvaukset leikkaavat vain fragmentteja todellisesta ja tekevät vääryyttä sen kompleksisuudelle. Kun yhdenlainen kohderajaus voi hyvinkin lämmittää kasvatuspsykologia, se samalla saattaa jättää koulutussosiologin kylmäksi. Koulutussosiologian ja -psykologian keskinäissuhteen käsitteellistäminen ei nykyisellään kuuluu kumpaankaan näistä. Adekvaattia kohdekonseptiota tavoitteleva arvioija törmää ongelmiin tilanteessa, jossa eri tutkimusperinteet viittaavat "samaan" sosiaalisen maailman tapahtumaan, mutta konstituoivat sen luonteeltaan ja rajoiltaan olennaisesti eri tavoin. Hänen tulisikin löytää sellainen metatason "palapeli”, jonka puitteissa nämä kaksi osaa täydentäisivät toisiaan ja tarjoaisivat täten yhdessä kokonaisemman kohdekuvauksen arvioinnin kiinnekohdaksi. Asiantuntijoiden taipumus esittää oma tietämyksensä maailman itsensä mittaisena ja kaiken olennaisen jo sisäänsäsulkevana on harhaanjohtavaa (ks. Huotari 1999). Se jättää merkittävän paikan kokonaismerkitystä tavoittelevalle arkikokemukselle ja maallikkoperspektiiville. 
Parempi arviointi, kun asiaa tarkastellaan arvioinnin käsitteen kautta, edellyttää sekä nykyistä kehittyneempiä malleja vallitsevasta kompleksisuudesta (C), laadukkaampia arvopäätelmän muodostamiskäytäntöjä (B) ja yhdenvertaisempaa tai edifioivampaa kanssakäymistä asiantuntijoiden ja asianosaisten välillä (A). Nämä määrittävät enemmänkin yleisiä, arviointia ja asiantuntijuuden kehittymistä siinä sääteleviä periaatteita kuin kriteerejä, jotka olisi mahdollista täyttää absoluuttisesti konkreettisissa arviointihankkeissa. Kohdekuvauksissa tai -malleissa kysymys on sekä aikaisempaa kuvaavampien teorioiden ja käsitteiden kehittämisestä että niiden poikkitieteellisestä tilannekohtaisesta soveltamisesta (vrt. Huotari 1997, 71-72). Arvoarvostelmien oikeuttamisessa on kysymys asianosaisuuden ja eroavuudet yksilöllisissä arvoarvostelmat paremmin tunnistavista ja osallistumisen yhdenvertaisuuden takaavista toimintamuodoista. Yhdessä nämä tarkoittavat kasvattavia ja molemminpuolista oppimista edistäviä arviointimuotoja.

\section{Lähteet}

AHONEN, P. (1998). Jotta arviointi olisi jotakin, se ei voi olla kaikkea. Hallinnon tutkimus (4), 257-261.

HOUSE, E. (1995). Evaluoinnin futuurinen perfekti. Teoksessa S. Takala (toim.) Arviointi ja koulutuksen laadun kehittäminen. Jyväskylän yliopisto. Kasvatustieteiden tutkimuslaitos, 23-32.

HUOTARI, V. (1997). Järjestelmärakenne koulutuksessa. Tampereen yliopisto. Acta Universistatis Tamperensis 548.

HUOTARI, V. (1999). Reduktionismi sosiaalisena ohjelmana ja koulutussosiologian institutionaalinen ehdollistuminen. Kasvatus 30 (1), 65-80.

RAIVOLA, R. (1995). Mitä evaluaatio on ja mihin sitä tarvitaan? Teoksessa A. Kajanto (toim.) Aikuiskoulutuksen arviointi - Panoraamoja ja lähikuvia. Kansanvalistusseura ja Aikuiskasvatuksen tutkimusseura. Aikuiskasvatuksen 36. vuosikirja. 7-60.

ROSSI, P. (1990)1 . Foreword. Teoksessa Chen, H. Theorydriven evaluations. Viewpoints on Educational and Human Services Evaluation. Dordrecht: Kluwer-Nijhoff.

VARTO, J. (1995). Aikuiskoulutuksen arvioinnin tehtävä ja ongelma. Teoksessa A. Kajanto (toim.) Aikuiskoulutuksen arviointi - Panoraamoja ja lähikuvia. Kansanvalistusseura ja Aikuiskasvatuksen tutkimusseura. Aikuiskasvatuksen 36. vuosikirja, 335-342.

VIRTANEN, P. (1998). Refleksiivinen evaluaatio ja tiedon hyödyntäminen. Hallinnon tutkimus (4), 262-271.

VUORENSYRJÄ, M. (1998). Julkisen hyödyke- ja palvelutarjonnan arviointi: arviointikäytäntöjen käsite- ja argumentaatioanalyysi koulutuksen alueella. Tampereen yliopisto. Politiikan tutkimuksen laitos. Jul- kaisematon lisensiaatin työ.

WILLIAMSON, B. (1998). Lifeworlds and Learning. Essays in the Theory and Practice of Lifelong Learning. Leicester: NIACE.

\section{Viitteet}

1 Kohdekonseptiota koskevat ongelmat nähdään helposti arviointikriteereiden outoutena. Niin viinien kuin koirienkin ammattimainen arviointi näyttäisi pintapuolisesti vaativan pitkäaikaista perehtymistä kyseiseen arviointitraditioon ja käytettyjen kriteereiden opiskelua. Todennäköisesti kuitenkin olettaisimme, jos päättäisimme heittäytyä tähän työhön, että viini säilyy edelleenkin viininä ja koira koirana. Tosiasiassa opettelisimme tällöin jäsentämään 'viinin' tai 'koiran' käsitteet uudelleen. Uusien käsitteiden myötä myös vastaavat arvioinnin kohteet näyttäytyisivät olemukseltaan uusina.

2 "Jos arvioija moniarvoisessa kohteessa omaksuu tuomarin ja lopullisen johtopäätöksentekijän roolin, hän väistämättä mitätöi joidenkin lähtöolettamukset ja loukkaa heidän arvojaan ja etujaan. Hän käyttää asiantuntijavaltaansa toisten eduksi ja toisten vahingoksi." (Raivola 1995, 36.)

3 Esimerkki Matti Vuorensyrjältä

Ainoaksi "oikeaksi" arviointipolitiikaksi nähdään helposti kaikkien asianosaisten sisällyttäminen arviointiprosessiin yhdenvertaisina osallistujina. Asianosaisuus määrittyy subjektivistisessa lähtökohdassa vain henkilön oman kokemuksen kautta. Jos hän katsoo, että arvioinnin kohteella on jokin merkityksellisen rooli tai asema hänen omassa elämänprojektissaan, hänen oma asianosaisuutensa samalla paljastuu hänelle itselleen. Asianosaisuus kytkeytyy tällöinkin kohdekonseptioon ja edelleen tieteelliseen tiedonmuodostukseen.

5 Jos ihmiset olisivat niin tietämättömiä oman it$\mathcal{~ s e n s a ̈ , ~ l a ̈ h i y m p a ̈ r i s t o ̈ n s a ̈ ~ j a ~ o m a n ~ t u l e v a i s u u t e n - ~}$ sa suhteen, ulkoavaruus olisi ilmeisesti ainoa paikka, josta heidän asiansa paremmin tuntevat henkilöt olisivat voineet ilmestyä. Mutta miksi näiden kahden ryhmän intressi olisi yhteinen? Miksi nämä "asiantuntijat" ajaisivat "asiakkaidensa" etua? Miksi tilanne ei olisi vastaava kuin kanan kasvattajan kohdalla, jota kanat mahdollisesti erehtyvät pitämään omana palvelijanaan, koska hän käy niitä säännöllisesti ruokkimassa?

6 Arviointi ei ole kohdetta "koskettamatonta" O toimintaa. Se voi vaikuttaa siihen tavalla, jota ei ole mahdollista huomioida kuin vasta myöhemmillä arviointikerroilla. Ahonen (1998, 261) listaakin arvioinnin uhkaksi sen, että arvioitavat toiminnot joutuvat kärsimään arviointivimmasta. Tässä suhteessa arvioinnin kohde onkin aina potentiaalisesti jotakin enemmän kuin vastaava kohdekonseptio.

Artikkeli saapui toimitukseen 26.1.2000.

Se hyväksyttiin julkaistavaksi 31.1.2000. 